Article

\title{
Capacitance Electrochemical pH Sensor Based on Different Hafnium Dioxide $\left(\mathrm{HfO}_{2}\right)$ Thicknesses
}

\author{
Zina Fredj ${ }^{1,2}$, Abdoullatif Baraket ${ }^{3, *}$, Mounir Ben Ali ${ }^{2}$, Nadia Zine ${ }^{3}$, Miguel Zabala ${ }^{4}$, Joan Bausells ${ }^{4}(\mathbb{D}$, \\ Abdelhamid Elaissari ${ }^{3}{ }^{\circ}$, Nsikak U. Benson ${ }^{5}{ }^{(0}$, Nicole Jaffrezic-Renault ${ }^{3}{ }^{\circ}$ and Abdelhamid Errachid ${ }^{3}$
}

check for updates

Citation: Fredj, Z.; Baraket, A.; Ben Ali, M.; Zine, N.; Zabala, M.; Bausells, J.; Elaissari, A.; Benson, N.U.; Jaffrezic-Renault, N.; Errachid, A.; et al. Capacitance Electrochemical $\mathrm{pH}$ Sensor Based on Different Hafnium Dioxide $\left(\mathrm{HfO}_{2}\right)$ Thicknesses.

Chemosensors 2021, 9, 13. https://doi. org $/ 10.3390 /$ chemosensors 9010013

Received: 3 December 2020

Accepted: 6 January 2021

Published: 10 January 2021

Publisher's Note: MDPI stays neutral with regard to jurisdictional clai$\mathrm{ms}$ in published maps and institutional affiliations.

Copyright: (C) 2021 by the authors. Licensee MDPI, Basel, Switzerland. This article is an open access article distributed under the terms and conditions of the Creative Commons Attribution (CC BY) license (https:// creativecommons.org/licenses/by/ $4.0 /)$.
1 NANOMISENE Lab, LR16CRMN01, Centre for Research on Microelectronics and Nanotechnology of Sousse, Technopole of Sousse B.P. 334, Sahloul, Sousse 4034, Tunisia; Zina.fredj@ISSATSO.rnu.tn

2 Higher Institute of Applied Sciences and Technology of Sousse, University of Sousse, 4003 Tunisia of Sousse, GREENS-ISSAT, Cité Ettafala, Ibn Khaldoun, Sousse 4003, Tunisia; Mounir.benali@ISSATSO.rnu.tn

3 Institut des Sciences Analytiques, University Claude Bernard Lyon 1, 5 rue de la Doua, F-69100 Villeurbanne, France; nadia.zine@univ-lyon1.fr (N.Z.); elaissari@lagep.univ-lyon1.fr (A.E.); nicole.jaffrezic@univ-lyon1.fr (N.J.-R.); abdelhamid.errachid@univ-lyon1.fr (A.E.)

4 Instituto de Microelectronica de Barcelona, IMB-CNM (CSIC), Campus UAB, 08193 Bellaterra, Barcelona, Spain; miguel.zabala@imb-cnm.csic.es (M.Z.); joan.bausells@imb-cnm.csic.es (J.B.)

5 Department of Chemistry, Covenant University, Ota KM. 10 Idiroko Road, Ota, Nigeria; nbenson@covenantuniversity.edu.ng

* Correspondence: Abdoullatif.baraket@ac-lyon.fr

\begin{abstract}
Over the past years, to achieve better sensing performance, hafnium dioxide $\left(\mathrm{HfO}_{2}\right)$ has been studied as an ion-sensitive layer. In this work, thin layers of hafnium dioxide $\left(\mathrm{HfO}_{2}\right)$ were used as $\mathrm{pH}$-sensitive membranes and were deposited by atomic layer deposition (ALD) process onto an electrolytic-insulating-semiconductor structure $\mathrm{Al} / \mathrm{Si} / \mathrm{SiO}_{2} / \mathrm{HfO}_{2}$ for the realization of a $\mathrm{pH}$ sensor. The thicknesses of the layer of the $\mathrm{HfO}_{2}$ studied in this work was 15, 19.5 and $39.9 \mathrm{~nm}$. $\mathrm{HfO}_{2}$ thickness was controlled by ALD during the fabrication process. The sensitivity toward $\mathrm{H}^{+}$ was clearly higher when compared to other interfering ions such as potassium $\mathrm{K}^{+}$, lithium $\mathrm{Li}^{+}$, and sodium $\mathrm{Na}^{+}$ions. Mott-Schottky and electrochemical impedance spectroscopy (EIS) analyses were used to characterise and to investigate the $\mathrm{pH}$ sensitivity. This was recorded by Mott-Schottky at $54.5,51.1$ and $49.2 \mathrm{mV} / \mathrm{pH}$ and by EIS at $5.86 \mathrm{p}\left[\mathrm{H}^{-1}\right], 10.63 \mathrm{p}\left[\mathrm{H}^{-1}\right], 12.72 \mathrm{p}\left[\mathrm{H}^{-1}\right]$ for 15, 19.5 and $30 \mathrm{~nm}$ thickness of $\mathrm{HfO}_{2}$ ions sensitive layer, respectively. The developed $\mathrm{pH}$ sensor was highly sensitive and selective for $\mathrm{H}^{+}$ions for the three thicknesses, 15, 19.5 and $39.9 \mathrm{~nm}$, of $\mathrm{HfO}_{2}$-sensitive layer when compared to the other previously mentioned interferences. However, the $\mathrm{pH}$ sensor performances were better with $15 \mathrm{~nm} \mathrm{HfO}_{2}$ thickness for the Mott-Schottky technique, whilst for EIS analyses, the $\mathrm{pH}$ sensors were more sensitive at $39.9 \mathrm{~nm} \mathrm{HfO}_{2}$ thickness.
\end{abstract}

Keywords: hafnium dioxide; ion-sensitive layer; $\mathrm{pH}$ sensors; $\mathrm{HfO}_{2}$ thickness; Mott-Schottky; electrochemical impedance spectroscopy

\section{Introduction}

The detection and control of $\mathrm{pH}$ are challenging for many environmental, biological and chemical processes that impact human lives [1]. One of the methods for controlling water and food quality is through the change in the $\mathrm{pH}$ value. Then, if the measured $\mathrm{pH}$ is not in the normal $\mathrm{pH}$ range, the quality of used water and food is questionable and should be discarded from normal use. In the case of water, for instance, leaching and nitrifying are indicated by low $\mathrm{pH}$ values as seen in the case of the presence of the proliferation of microorganisms in water [2]. The conventional analytical process for water quality monitoring consists of multiple steps: water sampling, sample transportation to laboratories and laboratory analysis. This approach is time-consuming, expensive and laboratory-dependent. In addition, the results are easily affected by anthropogenic interference as well as long-term 
storage of the water samples. For example, conventional glass $\mathrm{pH}$ electrodes are brittle, large in dimensions, slow in response and costly, and they need regular maintenance such as calibration and refilling of the reference buffer solution [3]. Therefore, a challenge is the development of new miniaturized sensors that promise higher-quality sensing with lower costs. For this, a number of methods for measuring $\mathrm{pH}$ have been reported such as potentiometric [4,5], capacitive [6], conductometric [7], luminescence [8], optical [9] and shape/mass $[10,11]$. However, the sensors in these emerging applications should be sensitive, fast, and compatible. In this regard, a range of materials and designs have been explored, but the semiconducting are particularly attractive as they allow fabricating miniaturized sensors with very fast response and excellent sensitivity on the variety of substrates and production can be scaled up.

In this context, the first selective ion field chemical sensor or ISFETs (Ion-Sensitive Field Effect Transistor) was developed in 1970 by P. Bergveld with silicon dioxide $\left(\mathrm{SiO}_{2}\right)$ as the sensing membrane [12]. These devices have been very successful in their applications in the medical field to monitor certain parameters in blood and urine samples because of their advantages, such as the low cost, fast response and the small sample volumes necessary to perform the analysis. However, this material quickly showed its limitations for $\mathrm{pH}$ measurement and its short lifetime. In recent years, to achieve better sensing performance, many materials, such as silicon nitride $\left(\mathrm{Si}_{3} \mathrm{~N}_{4}\right)$ [13], aluminium oxide $\left(\mathrm{Al}_{2} \mathrm{O}_{3}\right)$ [14], Si nanowire $/ \mathrm{SiO}_{2} / \mathrm{Al}_{2} \mathrm{O}_{3}$ [15], Erbium oxide $\mathrm{Er}_{2} \mathrm{O}_{3}$, Tantalum oxide $\left(\mathrm{Ta}_{2} \mathrm{O}_{5}\right)$ [16], Tin Oxide $\left(\mathrm{SnO}_{2}\right)$ [17], and Titanium oxide $\left(\mathrm{TiO}_{2}\right)$ [18] have been used as ion-sensitive layers or $\mathrm{pH}$ sensors. Among numerous proposed high dielectric constant $\mathrm{K}$ (high-k) of metal oxides reported in the literature, hafnium dioxide $\left(\mathrm{HfO}_{2}\right)$ has a high $\mathrm{pH}$ sensitivity, low drift voltage, low hysteresis and low body effect and is promising as a $\mathrm{pH}$ sensing material [19-21] in electrolyte-insulator-semiconductor structures. In particular, $\mathrm{HfO}_{2}$ was studied as a $\mathrm{pH}$-sensing membrane in ion-sensitive field-effect transistors (ISFETs) and showed good sensitivity [22]. $\mathrm{HfO}_{2}$ has a medium permittivity $(\varepsilon \sim 16-19$ for the monoclinic phase) and a reasonably high bandgap $(5.7 \mathrm{eV})$ with a suitable band offsets on silicon and exhibits good chemical stability in contact with $\mathrm{Si}$ and $\mathrm{SiO}_{2}$. It is also a promising dielectric oxide for advanced applications, such as metal-insulator-metal (MIM) capacitors, which are present in the upper level of integrated circuits (ICs). In the numerous publications reported so far on $\mathrm{HfO}_{2}$ for microelectronic applications, atomic layer deposition (ALD) and CVD have been widely used for films preparation. These chemical routes offer the advantage of possible planar and non-planar surface functionalization at industrial scale [23]. ALD is a very attractive technique for growing a high-quality thin layer onto various substrates. The key benefit of ALD is related to its ability to control the deposition on an atomic scale, while the growth of the ALD film is self-limited and based on surface reaction [24]. For this reason, this method has recently become the decision-making process of the semiconductor company's components to treat conformally very thin insulating layers. [25].

In the present work, the $\mathrm{pH}$ sensing properties of $\mathrm{HfO}_{2}$ thin films with various thicknesses induced by atomic layer deposition were investigated using an electrolyteinsulator-semiconductor structure. The $\mathrm{pH}$ sensing properties of a dielectric material should not depend on the thickness of the dielectric layer. These properties should depend on surface charge-exchange sites. However, the devices are used in an aqueous medium, and therefore hydration of the initial layers can affect the sensing properties. $\mathrm{HfO}_{2}$ layers used in transistors are typically very thin and in the range of 10 to $20 \mathrm{~nm}$. Consequently, the investigation of their $\mathrm{pH}$ sensitivity as a function of layer thickness will be of great interest.

The electrolyte-insulator-semiconductor structure is a capacitive sensor based on the changes of the surface potential between the electrolyte and the detection insulator, which could be measured as a function of the offset of the capacitance-voltage curves $(\mathrm{C}(\mathrm{V}))$. This structure is ranked among the simplest platforms as a replacement of ISFET for the preliminary investigation of the properties of new detection materials. Electrochemical impedance spectroscopy was used to investigate the $\mathrm{pH}$ sensitivity for the various $\mathrm{HfO}_{2}$ 
thicknesses. The relationship between the impedance behaviour and the solution $\mathrm{pH}$ for such an electrolyte-insulator-semiconductor has been rarely studied, which stimulates this study and also the effect of interfering ions via electrochemical technique for a potential pH-sensitive material.

\section{Materials and Methods}

\subsection{Chemical and Reagent}

All chemicals were commercial products, including Tris(hydroxymethyl)aminomethane (TRIS), magnesium nitrate $\left(\mathrm{Mg}\left(\mathrm{NO}_{3}\right)_{2}\right)$, potassium hydroxide $(\mathrm{KOH})$, lithium perchlorate $\left(\mathrm{ClLiO}_{4}\right)$ and sodium nitrate $\left(\mathrm{NaNO}_{3}\right)$ and were purchased from Fluka analytical grade reagents. The $\mathrm{pH}$ of the solution was adjusted via the addition of $1.0 \mathrm{M}$ hydrochloric acid $(\mathrm{HCl}, 37 \%)$ obtained from Sigma-Aldrich. All reagent solutions were prepared in double-distilled water.

\subsection{Substrates Fabrication}

The hafnium dioxide $\left(\mathrm{HfO}_{2}\right)$ substrate was fabricated by the atomic layer deposition (ALD) technique. This technique allows the deposition of very thin layers by sequential self-terminating gas-solid reactions [26,27]. The hafnium dioxide $\mathrm{pH}$ sensor was fabricated from a p-type silicon wafer with $100 \mathrm{~mm}$ diameter, $<100>$ orientation and $4-40 \mathrm{~W} \cdot \mathrm{cm}^{-1}$ resistivity. Here, a thin layer of $78 \mathrm{~nm}$ thickness of silicon dioxide $\left(\mathrm{SiO}_{2}\right)$ was grown thermally on the silicon surface followed by a deposition of $\mathrm{HfO}_{2}$. The principle of the ALD consists of successive and sequential surface treatment to obtain ultra-thin layers. Typically, the precursors of the deposition cycle are in fact introduced sequentially into the reaction chamber, and each injection of precursor is separated by a purging of the reactor using a neutral gas. The first precursor is introduced under gas state, and some molecules are adsorbed on the surface of the substrate. The adsorption process continues until the surface is completely saturated with a precursor monolayer. Thereafter, a neutral gas is introduced into the reaction chamber in order to clean the surface of the substrate and also the chamber. The precursor molecules remaining in the gas phase are then removed. Then, the second precursor is injected and reacts with the monolayer of the first adsorbed precursor, leading to the growth of the film. Finally, a second purge is carried out, in order to eliminate the reaction products as well as the molecules of the second precursor present in the gas phase. The thickness of the deposited $\mathrm{HfO}_{2}$ layer is proportional to the number of ALD cycles performed. With these process conditions, 100 cycles typically result in a thickness of $10.5 \mathrm{~nm}$ [26]. Finally, the electrical contact on the silicon backside was obtained by deposition of 500 nm-thick $\mathrm{Al}(99.5 \%) / \mathrm{Cu}(0.5 \%)$ layers on the back of the silicon wafers [28]. The wafers were then diced into chips of $10 \mathrm{~mm} \times 10 \mathrm{~mm}$ and were ready for electrochemical characterization.

Prior to any $\mathrm{pH}$ measurements, the hafnium dioxide substrates were cleaned with acetone for $15 \mathrm{~min}$ in an ultrasonic bath, dried with a nitrogen stream and finally treated by UV irradiation for 30 min using UV-Ozone cleaner (equipment ProCleaner TM Plus from Bioforce). This cleaning process was necessary to eliminate all organic contamination provided for residual resins of the $\mathrm{HfO}_{2}$ fabrication process.

Standard surface characterisations of $\mathrm{HfO}_{2}$ layers deposited by the same ALD process have been thoroughly reported in the literature. Gemma Martín et al. [29] have reported the characterization of the ALD-HfO2 structure by Transmission Electron Microscopy (TEM) and by using electron energy loss spectroscopy (EELS). The TEM images have shown successful growth of $\mathrm{HfO}_{2}$ thin films on silicon substrates. Further, the developed $\mathrm{HfO}_{2}$ structures have been characterized through their electrical properties by Hector Garcia et al. [30]. The measurement of C(V) and current-voltage (I-V) characteristics have been carried out in order to study the dielectric reliability of the developed $\mathrm{HfO}_{2}$ layers. The authors concluded that the structure realised at $150{ }^{\circ} \mathrm{C}$ exhibits both the greatest breakdown voltage and the greatest equivalent oxide thickness (EOT) values, making it the most advantageous condition studied for the reliability of the layer. 


\subsection{Electrochemical Measuring Set-Up}

Mott-Schottky and electrochemical impedance spectroscopy (EIS) analyses electrochemical analyses were performed by using potentiostat (VMP3 instruments 16 channels BioLogic France). The experiments were performed at room temperature in a dark and grounded metal box to avoid photo-induction charges in the semiconductor structure.

Figure 1 shows the electrochemical cell used for both capacitance and EIS measurements for the $\mathrm{pH}$ variation. The electrolyte insulator semiconductor was used with external auxiliary platinum counter electrode (CE) and saturated calomel electrode (SCE) as reference electrode (RE) from (Radiometer Analytical, France). The $\mathrm{Al} / \mathrm{Si} / \mathrm{SiO}_{2} / \mathrm{HfO}_{2}$ structure used as working electrode (WE) and was fixed at the bottom of the electrochemical cell. The electrical contact was realised from the back side of the WE. Mott-Schottky analyses were carried out for $\mathrm{pH}$ study following the capacitance $(\mathrm{C})$ variation versus the measured potential $(\mathrm{V}) . \mathrm{C}(\mathrm{V})$ measurements were performed at the optimized frequency of $100 \mathrm{~Hz}$ and with a signal amplitude of $25 \mathrm{mV}$.

(A)

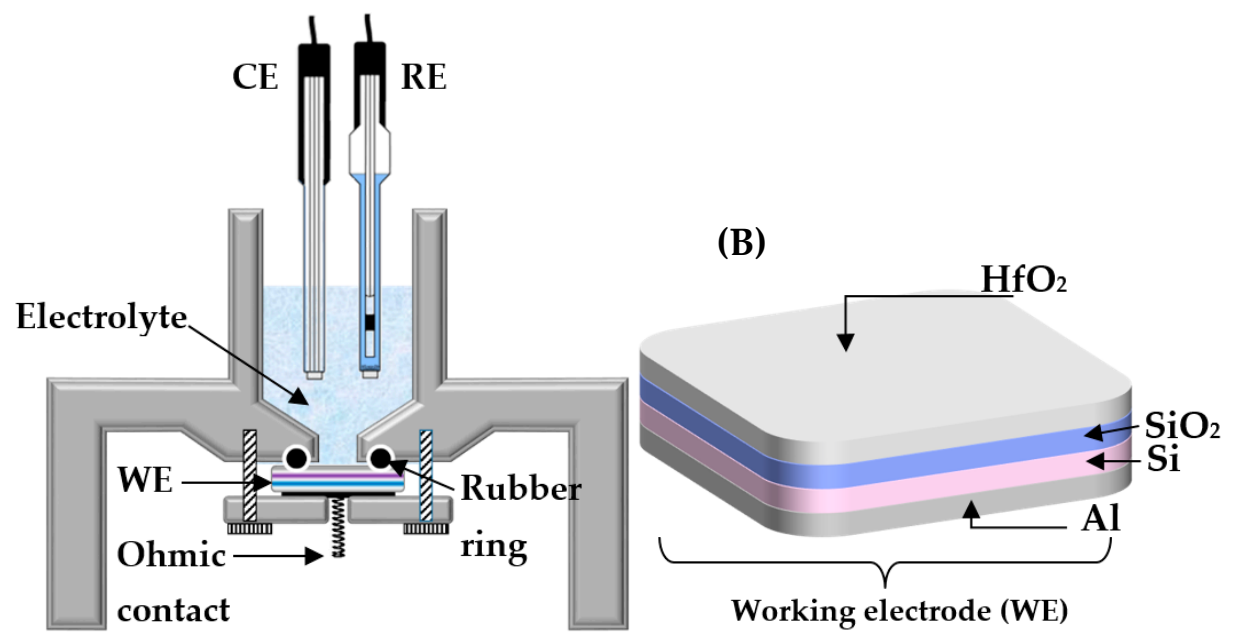

Figure 1. (A) Electrochemical cell used for $\mathrm{pH}$ measurement with Calomel-Saturated Reference electrode (RE), counter electrode (CE), and Ohmic contact behind the WE; (B) working electrode with electrolytic-insulating-semiconductor structure based on $\mathrm{Al} / \mathrm{Si} / \mathrm{SiO}_{2} / \mathrm{HfO}_{2}$.

The electrolyte used for both electrochemical characterizations of $\mathrm{pH}$ study was made from $0.4 \mathrm{M}\left(\mathrm{Mg}\left(\mathrm{NO}_{3}\right)_{2}\right)$ in $5 \mathrm{mM}$ Tris(hydroxymethyl)aminomethane, TRIS). The $\mathrm{pH}$ was adjusted using $1 \mathrm{M} \mathrm{HCl}$ solution. The $\mathrm{pH}$ values were controlled before and after the $\mathrm{C}(\mathrm{V})$ measurements by a $\mathrm{pH}$ meter (HI 98130, HANNA).

The electrochemical impedance spectroscopy (EIS) measurements were recorded by applying a sinusoidal potential amplitude of $25 \mathrm{mV}$ and an optimized polarization potential fixed at $-0.3 \mathrm{~V}$ within the frequency range of $100 \mathrm{mHz}$ to $100 \mathrm{kHz}$ using a VMP3 Bio-Logic Science Instrument, France. The $\mathrm{pH}$ variation was quantified by the variation of transfer charge resistance Rtc. This parameter was extracted from Nyquist plots of the impedance data using EC-Lab V11.36 modelling software (Bio-Logic Science Instrument, France). EIS data were fitted using Z-fit with Randomize + Simplex method. Randomize was stopped on 100,000 iterations, and the fit stopped on 5000 iterations.

\section{Results}

\subsection{Hafnium Dioxide Surface Characterization}

Wettability study was used to characterize the $\mathrm{HfO}_{2}$ surface before and after activation by measuring the water contact angle. Figure 2 shows the evolution of the water contact angle as a function of the treatments achieved on the surfaces of transducers based on $\mathrm{HfO}_{2}$. Contact angles of $77.16^{\circ}, 74.06^{\circ}, 72.19^{\circ} \pm 1^{\circ}$ were measured, showing the slightly hydrophobic character of the $\mathrm{HfO}_{2}$ for the thicknesses of 15.0, 19.5 and $39.9 \mathrm{~nm}$, respectively. 
After activation of $\mathrm{HfO}_{2}$ surface with $\mathrm{UV} /$ ozone, the contact angles were sharply decreased to $20.34^{\circ}, 15.56^{\circ}, 13.48^{\circ} \pm 1^{\circ}$. $\mathrm{HfO}_{2}$ became highly hydrophilic as already reported by Braik et al. [31].

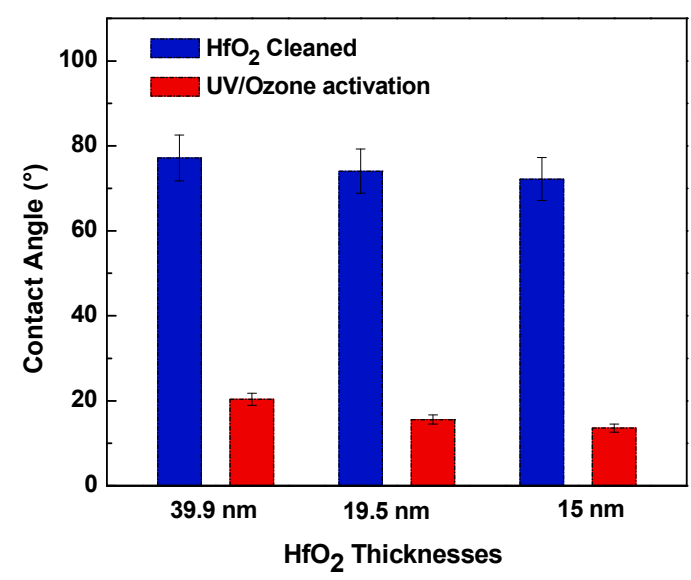

Figure 2. Contact angle measurements of the $\mathrm{HfO}_{2}$ surface for the three thicknesses of 15.0, 19.5 and $39.9 \mathrm{~nm}$ used for the $\mathrm{pH}$ sensor based on $\mathrm{Al} / \mathrm{Si} / \mathrm{SiO}_{2} / \mathrm{HfO}_{2}$.

\subsection{Frequency Optimization}

The capacitance as a function of the potential $(\mathrm{C}(\mathrm{V})$ curves) was measured within a wide frequency range from $10 \mathrm{mHz}$ to $10 \mathrm{kHz}$ to characterise the frequency effect on the $\mathrm{pH}$ sensor. $\mathrm{C}(\mathrm{V})$ curves in Figure 3 were recorded by using the capacitive chemical sensor in a solution of $0.4 \mathrm{M}\left(\mathrm{Mg}\left(\mathrm{NO}_{3}\right)_{2}\right)$ at $\mathrm{pH} 7.4$ (adjusted with Tris).

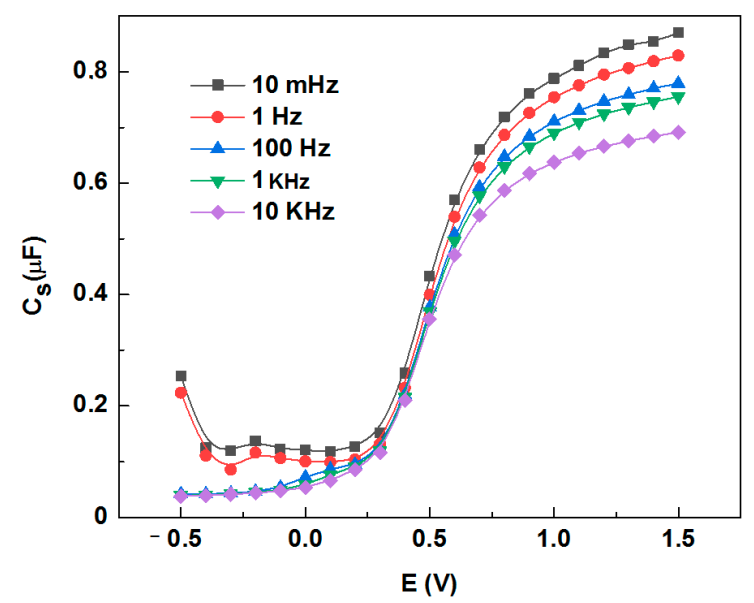

Figure 3. Typical C(V) response to frequency changes from $100 \mathrm{mHz}$ to $100 \mathrm{kHz}$.

$\mathrm{C}(\mathrm{V})$ analyses show a normal behaviour of the capacitance chemical sensor as recently reported in the literature [32]. However, the $\mathrm{pH}$ sensor shows at low frequency $(10 \mathrm{mHz}$ and $1 \mathrm{~Hz}$ ) a background noise at $0.5 \mathrm{~V}$. For high frequencies at $10 \mathrm{KHz}$, the $\mathrm{pH}$ sensor shows low capacitance at $1.5 \mathrm{~V}$. The optimized frequency was $100 \mathrm{~Hz}$, since it provides a good flat band and symmetric capacitance variation within the potential range of $-0.5 \mathrm{~V}$ to $1.5 \mathrm{~V}$.

\subsection{Mott-Schottky Analyses for $\mathrm{pH}$ Sensibility and Selectivity}

The $\mathrm{pH}$-sensitive sensor based on $\mathrm{HfO}_{2}$ was characterized by the Mott-Schottky technique through $\mathrm{C}(\mathrm{V})$ curves variation for the three $\mathrm{HfO}_{2}$ thicknesses $(15.0,19.5$ and $39.9 \mathrm{~nm})$ as shown in Figure 4. C(V) curves were recorded at $100 \mathrm{~Hz}$ for each thickness at $\mathrm{pH} 9,7,5$ and 3 as shown in Figure 4. A shift was observed of the flat band of $C(V)$ 
curves to positive potential $\Delta \mathrm{V}_{\mathrm{FB}}$ as the concentration of hydrogen ions was increased ( $\mathrm{pH}$ decrease) for the three thicknesses.
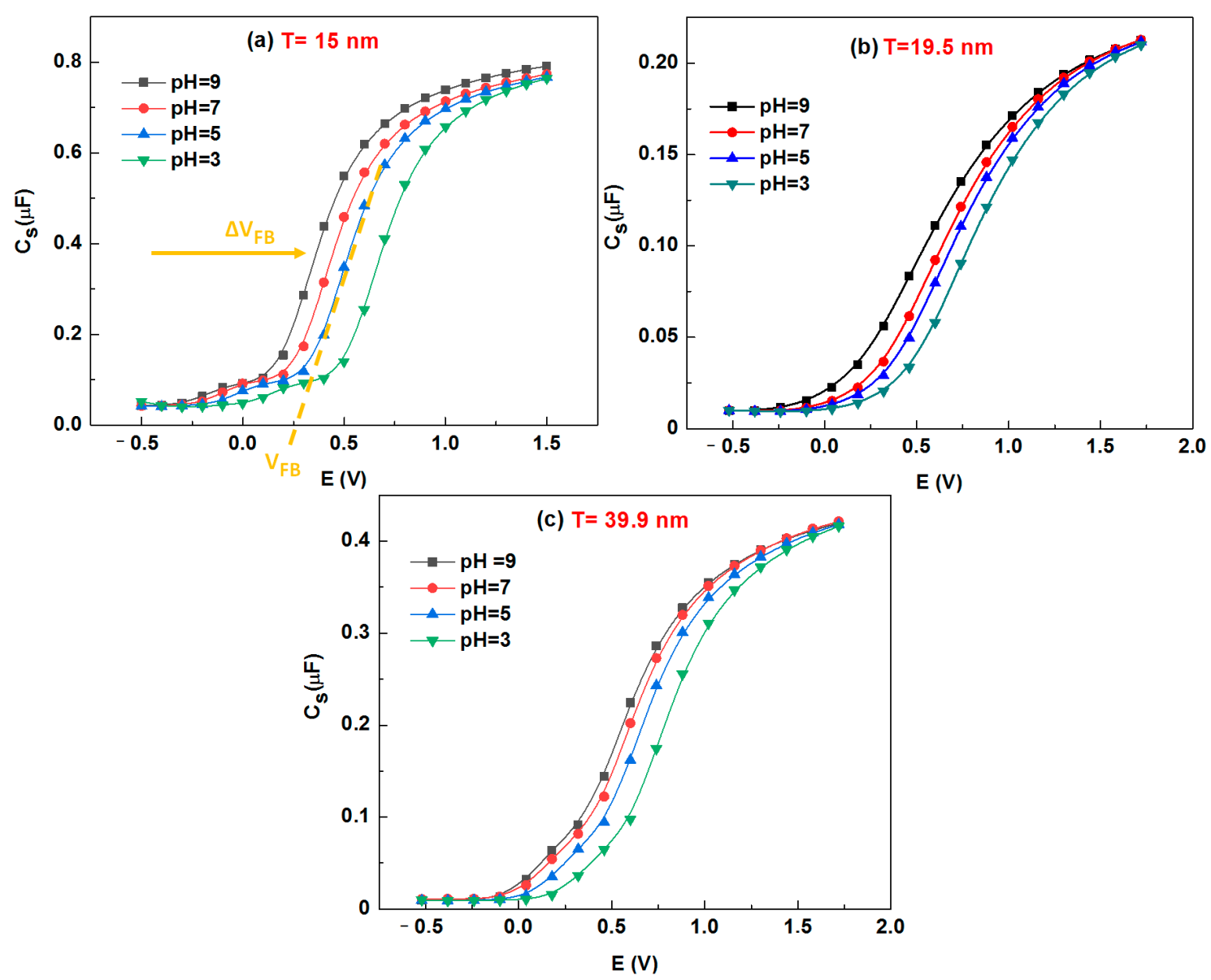

Figure 4. Typical $\mathrm{C}(\mathrm{V})$ curves for different hafnium thicknesses (a) $15.0 \mathrm{~nm}$, (b) $19.5 \mathrm{~nm}$ and (c) 39.9 nm stacked $\mathrm{HfO}_{2}$ structures for various $\mathrm{pH}$ buffer solutions using $0.4 \mathrm{M} \mathrm{Mg}\left(\mathrm{NO}_{3}\right)_{2}$ prepared in TRIS buffer. The $\mathrm{pH}$ was adjusted by the $\mathrm{HCl}$ solution $(\mathrm{C}=1 \mathrm{M})$.

Therefore, the $\Delta \mathrm{V}_{\mathrm{FB}}$ variation was due to the $\mathrm{H}^{+}$ions exchange at the electrodeelectrolyte interface between $\mathrm{HfO}_{2}$ surface and the conductive aqueous solution $\left(0.4 \mathrm{~mol} \cdot \mathrm{L}^{-1}\right.$ $\mathrm{Mg}\left(\mathrm{NO}_{3}\right)_{2}$ prepared in TRIS buffer). Due to the hydrogen ion interactions with the hafnium dioxide surface, how has specific sites that can bind hydrogen ions from the solution, this gave rise to $\mathrm{pH}$-dependent surface charge density [33]. This distribution of protons $\left(\mathrm{H}^{+}\right)$ on the $\mathrm{HfO}_{2}$ surface results in the formation of a dipole layer at the electrode-electrolyte interface, which affects the flat band potential $\mathrm{V}_{\mathrm{FB}}$ of the ion-sensitive capacitance sensor as a function of the $\mathrm{pH}$ variation.

A high sensitivity to $\mathrm{pH}$ as the $\mathrm{HfO}_{2}$ surface decrease (Figure 5) was observed. The values of $\mathrm{V}_{\mathrm{FB}}$ potential in solution at each thickness were extracted from the $\mathrm{C}(\mathrm{V})$ curves. The $\mathrm{pH}$ sensitivity (S) is defined in Equation (1).

$$
S=\frac{\Delta \mathrm{V}_{\mathrm{FB}}}{\Delta \mathrm{pH}}
$$




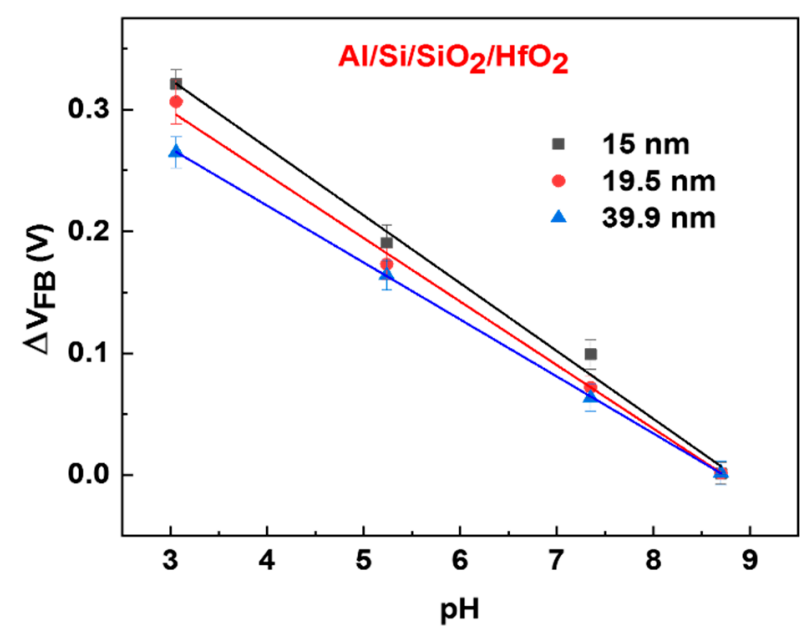

Figure 5. The $\mathrm{pH}$ sensitivity for three $\mathrm{HfO}_{2}$ thicknesses (15.0, 19.5 and $\left.39.9 \mathrm{~nm}\right): \Delta \mathrm{V}_{\mathrm{FB}}$ as a function of $\mathrm{pH}$ (from 3 to 9).

Therefore, the $\mathrm{pH}$ sensitivity can be calculated by linear fitting $\Delta \mathrm{V}_{\mathrm{FB}}$ and the corresponding $\mathrm{pH}$ of the buffer solution in the $\mathrm{pH}$ range from 3 to 9 . The corresponding values are shown in Table 1.

Table 1. Comparison of the sensitivity of various $\mathrm{HfO}_{2}$ thicknesses.

\begin{tabular}{cccc}
\hline Thicknesses $(\mathrm{nm})$ & 15 & 19.5 & 39.9 \\
Sensitivity $(\mathrm{mV} / \mathrm{pH})$ & 54.5 & 51.1 & 49.2 \\
$\mathrm{R}^{2}$ & 0.9966 & 0.9957 & 0.9926 \\
\hline
\end{tabular}

As previously mentioned, the sensitivity of the hafnium structures versus the $\mathrm{pH}$ variation increased as the thickness decreased. The highest $\mathrm{pH}$ sensitivity of the hafnium electrolytic-insulating-semiconductor structure of $54.5 \mathrm{mV} / \mathrm{pH}$ was observed for $15 \mathrm{~nm}$ $\mathrm{HfO}_{2}$ thickness. The thicker the $\mathrm{HfO}_{2}$ layer, the further the $\mathrm{H}^{+}$proton layer is from the $\mathrm{Al} / \mathrm{Si} / \mathrm{SiO}_{2} / \mathrm{HfO}_{2}$ capacitance structure which makes the ion sensor less sensitive.

The capacitance-ion-sensitive $\mathrm{pH}$ sensor is more sensitive for thin layers of $\mathrm{HfO}_{2}$. However, at less than $5 \mathrm{~nm} \mathrm{HfO}$ thickness, it is possible to have background noise and less sensitivity using $C(V)$ analyses. This has been reported by Wang et al. [34] using thin $\mathrm{HfO}_{2}$ layers with different thicknesses (3.5, 5, 7.5 and $10 \mathrm{~nm}$ ) deposited on p-type silicon wafers to measure the $\mathrm{pH}$ within the range of 2 to 12 through the capacitance-voltage $\mathrm{C}(\mathrm{V})$ measurements. By using the $\mathrm{HfO}_{2}$ film with a thickness of $10 \mathrm{~nm}$, the authors found a sensitivity around $40-45 \mathrm{mV} / \mathrm{pH}$. However, when a layer of $3.5 \mathrm{~nm}$ thickness was used, the $\mathrm{C}(\mathrm{V})$ curves were unstable in the acidic range (low $\mathrm{pH}$ ) and were discussed in terms of the leakage current of the thin layer of $\mathrm{HfO}_{2}$. In the present work, we have a quasi-Nernstian $\mathrm{pH}$ response $(54.5 \mathrm{mV} / \mathrm{pH})$ of the $\mathrm{pH}$ sensor based on $\mathrm{HfO}_{2}$ with $15 \mathrm{~nm}$ thickness. Owing to general requirements concerning the reduction of the sensor's size and the increase in its reliability, the thin $\mathrm{HfO}_{2}$ film is a potential candidate as a sensing layer for $\mathrm{pH}$ sensor applications.

The selectivity of the developed $\mathrm{pH}$ sensor was studied by using other potential interfering ions like $\mathrm{K}^{+}, \mathrm{Li}^{+}$and $\mathrm{Na}^{+}$prepared in $10 \mathrm{mM}$ TRIS-HCl buffer $\mathrm{pH}=7.4$ (Figure 6). Indeed, we can clearly observe a negligible response of the $\mathrm{pH}$ sensor for the interfering ions as the flat band potential variation $\Delta \mathrm{V}_{\mathrm{FB}}$ of $\mathrm{C}(\mathrm{V})$ curves was too weak (Table 2, Figure 6 Inset and Figure $\mathrm{S} 1$ in Supplementary Material). 

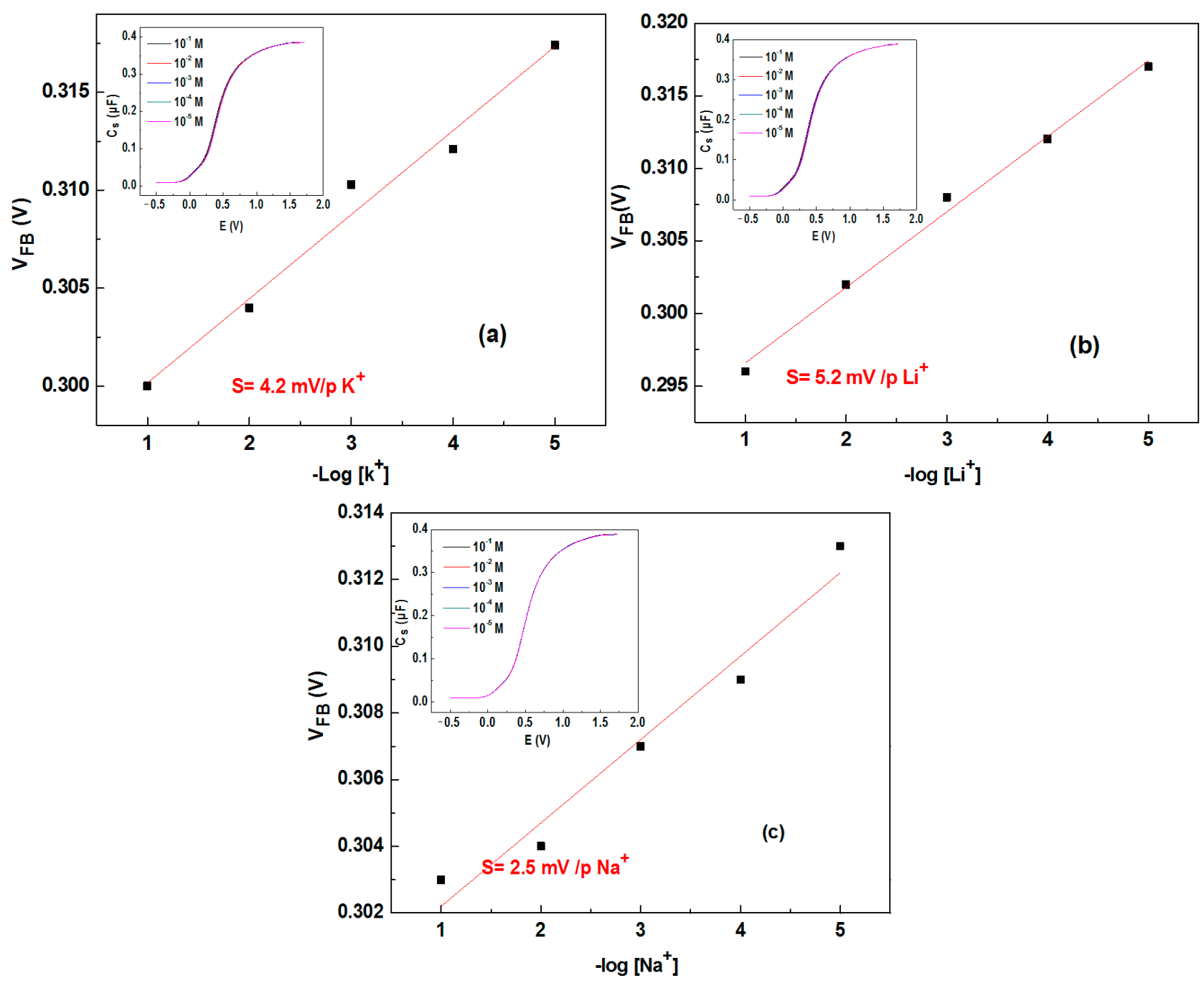

Figure 6. The flat band potential $\mathrm{V}_{\mathrm{FB}}$ variation versus (a) $\mathrm{K}^{+},(\mathbf{b}) \mathrm{Li}^{+}$and (c) $\mathrm{Na}^{+}$concentrations from $10^{-5} \mathrm{M}^{-10} 10^{-1} \mathrm{M}$. Inset: the capacitive responses of $\mathrm{Si} / \mathrm{SiO} 2 / \mathrm{HfO}_{2}$ structure with $15 \mathrm{~nm} \mathrm{HfO}_{2}$ thickness for interfering ions (Figure $\mathrm{S} 1$ in Supplementary Material).

Table 2. Sensitivities and dynamic ranges obtained with the implanted structure for $\mathrm{K}^{+}, \mathrm{Li}^{+}$and $\mathrm{Na}^{+}$ detection $\left(10^{-5} \mathrm{M}\right.$ to $\left.10^{-1} \mathrm{M}\right)$.

\begin{tabular}{cccc}
\hline Ion & $\mathbf{K}^{+}$ & $\mathbf{L i}^{+}$ & $\mathbf{N a}^{+}$ \\
\hline Sensibility $(\mathrm{mV} / \mathrm{p}[\mathrm{X}])$ & 4.2 & 5.2 & 2.5 \\
$\mathrm{R}^{2}$ & 0.974 & 0.992 & 0.952 \\
\hline
\end{tabular}

\subsection{Electrochemical Impedance Spectroscopy Measurements for $\mathrm{pH}$ Variation}

\subsubsection{Electrochemical Parameter Optimization}

Electrochemical impedance spectroscopy (EIS) was used to study the $\mathrm{pH}$ variation. The $\mathrm{HfO}_{2} \mathrm{pH}$ sensor was used as a working electrode in a conventional three-electrode electrochemical cell to optimise the measurement conditions in terms of frequency and potential. As the EIS optimization parameter, we used the $15 \mathrm{~nm} \mathrm{HfO} 2$ thickness as it gave high sensitivity in the Mott-Schottky study. At the frequency range from $0.1 \mathrm{~Hz}$ to $100 \mathrm{kHz}$, different potentials were applied to choose the appropriate potential to minimize the Warburg impedance result of the diffusion process (Figure 7). Under voltages +0.1 , $-0.1,-0.2$ and $-0.3 \mathrm{~V}$ of the hafnium working electrode versus the SCE reference electrode, 
the total impedance decreased sharply under negative polarization as a result of a decrease in the Warburg impedance.

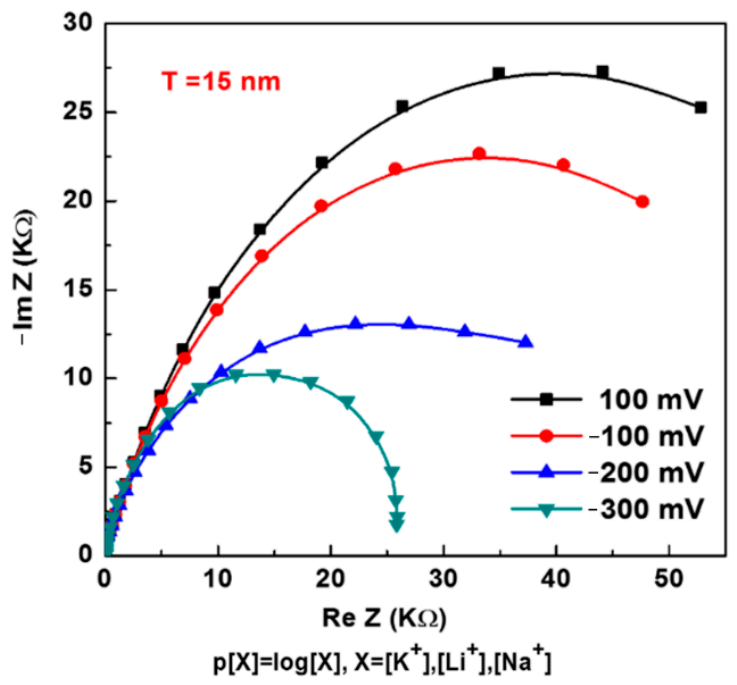

Figure 7. Impedance spectra (in Nyquist presentation) of the $\mathrm{HfO}_{2}$ structures for different polarizations vs. saturated calomel reference electrode (SCE). Electrochemical impedance spectroscopy (EIS) measurements were carried out in $0.4 \mathrm{~mol} \cdot \mathrm{L}^{-1} \mathrm{Mg}\left(\mathrm{NO}_{3}\right)_{2}$ prepared in TRIS buffer using the following conditions: frequency range from $100 \mathrm{mHz}$ to $100 \mathrm{kHz}, \mathrm{AC}$ amplitude voltage at $25 \mathrm{mV}$.

The optimum conditions selected for further measurements were $100 \mathrm{mHz}$ to $100 \mathrm{kHz}$ frequency range, AC amplitude voltage of $25 \mathrm{mV}$, and DC amplitude voltage of $-300 \mathrm{mV}$. These parameters were also applied to the other $\mathrm{HfO}_{2}$ thicknesses of 19.5 and $39.9 \mathrm{~nm}$.

\subsubsection{Impedance Analysis of the $\mathrm{pH}$ Sensor}

As we mentioned previously, $\mathrm{HfO}_{2}$ have specific sites that can bind hydrogen ions from the solution. The interactions of hydrogen ions with the $\mathrm{HfO}_{2}$ surface create a distribution of $\mathrm{H}^{+}$protons on the $\mathrm{HfO}_{2}$ surface results in the formation of a dipole layer at the electrode-electrolyte interface. For EIS measurements, the electron charge transfer resistance $\left(R_{t c}\right)$ at this interface increases or decreases depending on how these ions are charged. Figure 8 illustrates Nyquist plots of the electrochemical impedance response of the $\mathrm{HfO}_{2} \mathrm{pH}$ sensor at different $\mathrm{H}^{+}$concentrations (different $\mathrm{pH}$ ).

We can clearly observe that at a low frequency, the impedance of the electrochemical system increases significantly with increasing $\mathrm{pH}$ value (decrease in $\mathrm{H}^{+}$ion concentrations). This variation is attributed to the increased charge transfer resistance $R_{t c}$ at the hafnium/electrolyte interface. Therefore, the high $\mathrm{H}^{+}$concentration favours the electron transfer charge, which generates a low impedance. In the same context, Michael Lee et al. demonstrated a high clear shift of the Rtc as a function of $\mathrm{pH}$ variation using an $\mathrm{HfO}_{2}$ ion-sensitive sensor. This response was due to the change in either the dielectric or the conductive properties on the metal oxide surface [35].

The electrode-electrolyte interface can be modelled from an impedimetric point of view by the equivalent Randles circuit [36]. In this model, generally, the $R_{s}$ represents the resistance of the electrolyte solution in series with the parallel combination of the double-layer capacitance CPE (constant phase element) and the charge transfer resistance $\mathrm{R}_{\mathrm{tc}}$ in series with the Warburg impedance $Z_{\omega}$. (Figure 9 Inset). This equivalent electrical circuit was used for fitting analyses to extract the $R_{t c}$ variation of Nyquist plot semicircles of each $\mathrm{pH}$. Fitting parameters are summarized in Tables S1-S3 in supplementary data for each $\mathrm{HfO}_{2}$ thicknesses. 

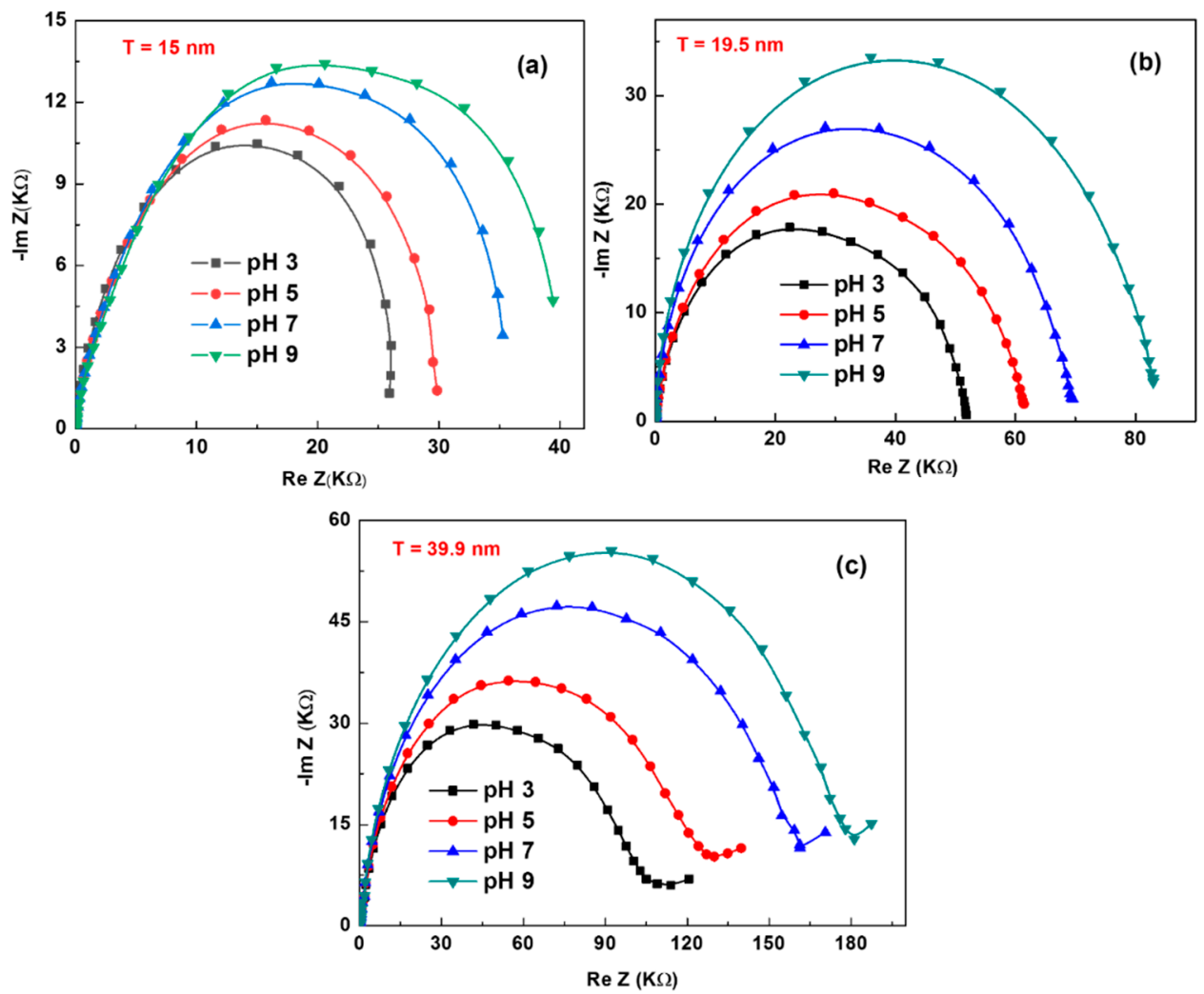

Figure 8. Nyquist plots at different $\mathrm{pH}$ for different hafnium thicknesses (a) $15.0 \mathrm{~nm}$, (b) $19.5 \mathrm{~nm}$ and (c) $39.9 \mathrm{~nm}$.

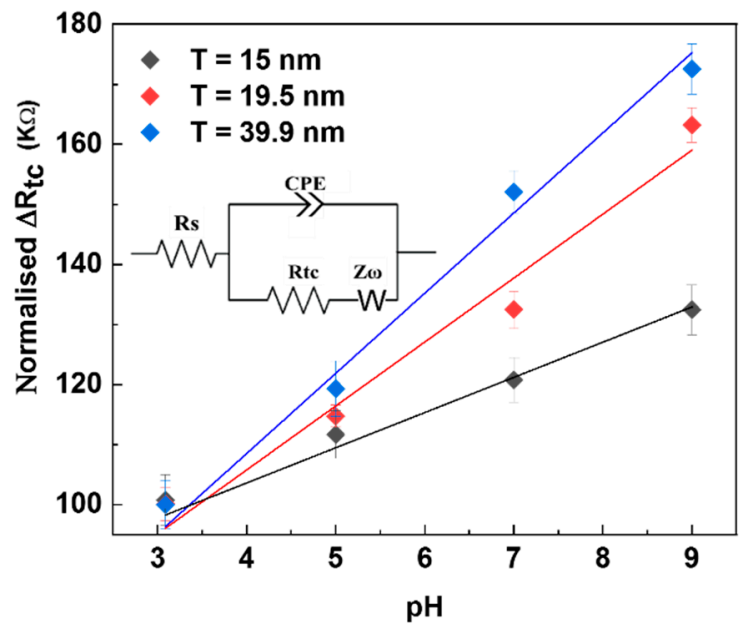

Figure 9. Calibration curve variation of normalized $\Delta \mathrm{R}_{\mathrm{ct}}$ as a function of the $\mathrm{pH}$ for different hafnium oxide thickness of $15.0 \mathrm{~nm}, 19.5 \mathrm{~nm}$ and $39.9 \mathrm{~nm}$.

The variation of the normalized $\Delta \mathrm{R}_{\mathrm{tc}}$ as a function of the hydrogen concentrations is presented in Figure 9 for different $\mathrm{HfO}_{2}$ thicknesses. A linear relationship was observed in the $\mathrm{pH}$ range from 3 to 9 . The corresponding sensitivities are $5.86 \mathrm{pH}^{-1}, 10.63 \mathrm{pH}^{-1}$ and $12.72 \mathrm{pH}^{-1}$ for $15.0 \mathrm{~nm}, 19.5 \mathrm{~nm}$ and $39.9 \mathrm{~nm}$, respectively.

Unlike the Mott-Schottky mode, the EIS measurement shows that 39.9 thickness was highly sensitive to $\mathrm{H}^{+}$protons when compared to $15 \mathrm{~nm}$ for $\mathrm{C}(\mathrm{V})$ measurement. This difference is surely due to the difference of the electrochemical parameters, which makes the $\mathrm{HfO}_{2}$ react differently with each technique. 


\subsubsection{The Selectivity of the Electrolyte Insulator Semiconductor Structure}

In order to confirm the sensitivity of $\mathrm{HfO}_{2}$ toward $\mathrm{H}^{+}$protons, other interferences for the quantitative determination of $\mathrm{pH}$ on the hafnium electrode $(39.9 \mathrm{~nm})$ were investigated using the same EIS measurements. The response of $\mathrm{HfO}_{2}$ with potassium, perchlorate and nitrate ions within the range between $10^{-5}$ to $10^{-1} \mathrm{M}$ prepared in TRIS-HCl Buffer [37] was investigated, and no significant changes of impedance spectroscopy spectra were found (Figure $\mathrm{S} 2$ in supplementary materials).

The same Randles equivalent circuit (Figure 9 Inset) was used to fit EIS analyses of the interferences in order to extract $\mathrm{R}_{\mathrm{tc}}$ variation. As can be observed in Figure 10, the $\mathrm{pH}$ sensor based on $\mathrm{Al} / \mathrm{Si} / \mathrm{SiO}_{2} / \mathrm{HfO}_{2}$ structures (thickness $39.9 \mathrm{~nm}$ ) was highly sensitive to $\mathrm{H}^{+}$protons with a sensitivity of $\left.12.72 \mathrm{p}^{-} \mathrm{H}^{+}\right]$when compared to the other interferences, which were found at $1.76 \mathrm{p}\left[\mathrm{K}^{-1}\right], 2.32 \mathrm{p}\left[\mathrm{Li}^{-1}\right]$ and $1.52 \mathrm{p}\left[\mathrm{Na}^{-1}\right]$.

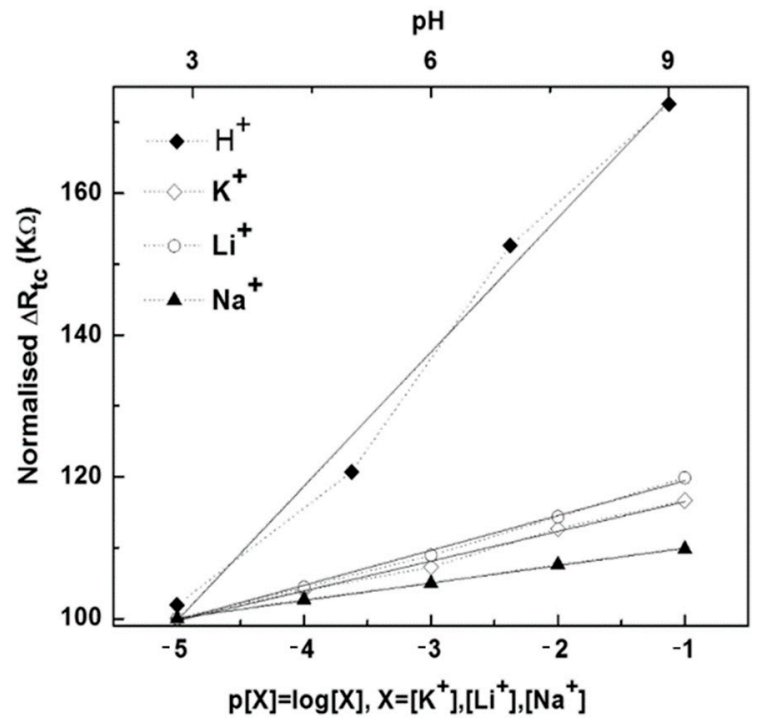

Figure 10. Calibration curve variation of normalized $\Delta \mathrm{R}_{\mathrm{ct}}$ as a function of the $\mathrm{pH}$ versus (a) $\mathrm{K}^{+}$, (b) $\mathrm{Li}^{+}$and (c) $\mathrm{Na}^{+}$concentrations from $10^{-5} \mathrm{M}$ to $10^{-1} \mathrm{M}$ at the $\mathrm{Si} / \mathrm{SiO}_{2} / \mathrm{HfO}_{2}$ structure (thickness 39.9 $\mathrm{nm})$.

\section{Conclusions}

In this work, we have studied the ability of the $\mathrm{HfO}_{2}$ non-functionalised transducer to detect the $\mathrm{pH}$ variation based on capacitive and impedimetric measurements. Furthermore, the effect of the thickness of the hafnium dioxide on the $\mathrm{pH}$ sensing properties was demonstrated. Both techniques EIS and Mott-Schottky for all thicknesses present a good sensitivity and selectivity against the interfering ions. Due to the uniform, smooth, conformal film deposition using ALD, the thickness of the $\mathrm{HfO}_{2}$ film can be reduced to $15 \mathrm{~nm}$ with good $\mathrm{pH}$ sensitivity $(54.5 \mathrm{mV} / \mathrm{pH})$ using Mott-Schottky, whilst for the EIS measurements, the $\mathrm{HfO}_{2}$ showed better sensitivity for 39.9 thickness.

Supplementary Materials: The following are available online at https:/ / www.mdpi.com/2227-9 040/9/1/13/s1, Figure S1: Typical C(V) for capacitance measurements of $\mathrm{Si} / \mathrm{SiO}_{2} / \mathrm{HfO}_{2}$ structure $15 \mathrm{~nm}$ using interfering ions (a) $\mathrm{K}^{+}$, (b) $\mathrm{Li}^{+}$, and (c) $\mathrm{Na}^{+}$with concentrations from $10^{-5} \mathrm{M}$ to $10^{-1} \mathrm{M}$. The flat band potential $\mathrm{V}_{\mathrm{FB}}$ variation was too weak when compared with Figure 1a, Figure S2: The impedimetric response of $\mathrm{Si} / \mathrm{SiO}_{2} / \mathrm{HfO}_{2}$ structure (thickness $15 \mathrm{~nm}$ ), versus (a) $\mathrm{K}^{+}$, (b) $\mathrm{Li}^{+}$, and (c) $\mathrm{Na}^{+}$concentrations from $10^{-5} \mathrm{M}$ to $10^{-1} \mathrm{M}$, Table $\mathrm{S} 1$ : Fitting data for $\mathrm{HfO}_{2}$ sensing substrate with a thickness of $15.0 \mathrm{~nm}$ for $\mathrm{pH}$ response, Table S2: Fitting data for $\mathrm{HfO}_{2}$ sensing substrate with a thickness of $19.5 \mathrm{~nm}$ for $\mathrm{pH}$ response, Table S3: Fitting data for $\mathrm{HfO}_{2}$ sensing substrate with a thickness of $39.9 \mathrm{~nm}$ for $\mathrm{pH}$ response. 
Author Contributions: A.E. (Abdelhamid Errachid), N.J.-R., A.E. (Abdelhamid Elaissari) and N.U.B. conceived and planned the experiments. M.B.A. and A.E. (Abdelhamid Errachid) supervised the findings of this work. Z.F. and A.B. carried out the experiments. M.Z. and J.B. contributed to the capacitance transducer fabrication and preparation. Z.F., N.Z. and A.E. (Abdelhamid Errachid) contributed to the interpretation of the results. Z.F. took the lead in writing the manuscript. A.B. and A.E. (Abdelhamid Errachid) supervised Z.F. for the manuscript writing. All authors provided critical feedback and helped shape the research, analysis and manuscript. All authors have read and agreed to the published version of the manuscript.

Funding: Funding through the European Union's Horizon 2020 research and innovation program entitled "An integrated POC solution for non-invasive diagnosis and therapy monitoring of Heart Failure patients, KardiaTool" under grant agreement No 768686. This work has made use of the Spanish ICTS Network MICRONANOFABS partially supported by MCIU.

Institutional Review Board Statement: Not applicable.

Informed Consent Statement: Not applicable.

Data Availability Statement: Raw data is available from the corresponding author.

Conflicts of Interest: We, the undersigned, Abdelhamid Errachid, Head of Department Micro and Nano BioTechnology at Institut des Sciences Analytiques, Université Claude Bernard Lyon 1, attest that we have no conflict of interest to declare for the present article entitled "The effects of Hafnium dioxide $\left(\mathrm{HfO}_{2}\right)$ thickness induced via atomic layer deposition on the $\mathrm{pH}$ sensing properties", which we are submitting to Analytical and Bioanalytical Chemistry for consideration and publication as a regular research paper. The submission is authored by Zina Fredj, Abdoullatif Baraket, Mounir Ben Ali, Nadia Zine, Miguel Zabala, Joan Bausells, Abdelhamid Elaissari, Nsikak U. Benson, Nicole Jaffrezic-Renault and Abdelhamid Errachidc. The authors' names mentioned above certify that they have NO affiliations with or involvement in any organization or entity with any financial or non-financial interest in the subject matter or materials discussed in this manuscript.

\section{References}

1. Qin, Y.; Kwon, H.-J.; Howlader, M.M.R.; Deen, M.J. Microfabricated electrochemical pH and free chlorine sensors for water quality monitoring: Recent advances and research challenges. RSC Adv. 2015, 5, 69086-69109. [CrossRef]

2. Eldridge, D.J.; Tozer, M.E. Environmental Factors Relating to the Distribution of Terricolous Bryophytes and Lichens in Semi-Arid Eastern Australia. Bryologist 1997, 100, 28-39. [CrossRef]

3. Yuqing, M.; Jianrong, C.; Keming, F. New technology for the detection of pH. J. Biochem. Biophys. Methods 2005, 63, 1-9. [CrossRef] [PubMed]

4. Ruan, C.; Ong, K.G.; Mungle, C.; Paulose, M.; Nickl, N.J.; Grimes, C.A. A wireless pH sensor based on the use of salt-independent micro-scale polymer spheres. Sens. Actuators B Chem. 2003, 96, 61-69. [CrossRef]

5. Bratov, A.; Abramova, N.; Ipatov, A. Recent trends in potentiometric sensor arrays-A review. Anal. Chim. Acta 2010, 678, 149-159. [CrossRef] [PubMed]

6. Ang, P.K.; Chen, W.; Wee, A.T.S.; Loh, K.P. Solution-Gated Epitaxial Graphene as pH Sensor. J. Am. Chem. Soc. 2008, 130, 14392-14393. [CrossRef] [PubMed]

7. Lesho, M.J.; Sheppard, N.F. Adhesion of polymer films to oxidized silicon and its effect on performance of a conductometric $\mathrm{pH}$ sensor. Sens. Actuators B Chem. 1996, 37, 61-66. [CrossRef]

8. Snee, P.T.; Somers, R.C.; Nair, G.; Zimmer, J.P.; Bawendi, M.G.; Nocera, D.G. A Ratiometric CdSe/ZnS Nanocrystal pH Sensor. J. Am. Chem. Soc. 2006, 128, 13320-13321. [CrossRef]

9. Kaval, N.; Seitz, W.R. Aminated poly(vinylbenzylchloride-co-2,4,5-trichlorophenyl acrylate) microspheres for optical pH sensing. In Proceedings of the SPIE, Boston, MA, USA, 9 December 1999; Volume 3860, pp. 224-231.

10. Cai, Q.Y.; Grimes, C.A. A remote query magnetoelastic pH sensor. Sens. Actuators B Chem. 2000, 71, 112-117. [CrossRef]

11. Cai, Q.Y.; Grimes, C.A. A salt-independent pH sensor. Sens. Actuators B Chem. 2001, 79, 144-149. [CrossRef]

12. Bergveld, P. Development of an Ion-Sensitive Solid-State Device for Neurophysiological Measurements. IEEE Trans. Biomed. Eng. 1970, 17, 70-71. [CrossRef] [PubMed]

13. Yin, L.T.; Chou, J.C.; Chung, W.Y.; Sun, T.P.; Hsiung, S.K. Characteristics of silicon nitride after O2 plasma surface treatment for pH-ISFET applications. IEEE Trans. Biomed. Eng. 2001, 48, 340-344. [PubMed]

14. Jakobson, C.G.; Dinnar, U.; Feinsod, M.; Nemirovsky, Y. Ion-sensitive field-effect transistors in standard CMOS fabricated by post processing. IEEE Sens. J. 2002, 2, 279-287. [CrossRef]

15. Knopfmacher, O.; Tarasov, A.; Fu, W.; Wipf, M.; Niesen, B.; Calame, M.; Schönenberger, C. Nernst limit in dual-gated Si-nanowire FET sensors. Nano Lett. 2010, 10, 2268-2274. [CrossRef] 
16. Mikolajick, T.; Kühnhold, R.; Ryssel, H. The pH-sensing properties of tantalum pentoxide films fabricated by metal organic low pressure chemical vapor deposition. Sens. Actuators B Chem. 1997, 44, 262-267. [CrossRef]

17. Chin, Y.-L.; Chou, J.-C.; Sun, T.-P.; Liao, H.-K.; Chung, W.-Y.; Hsiunga, S.-K. A novel SnO2/Al discrete gate ISFET pH sensor with CMOS standard process. Sens. Actuators B Chem. 2001, 75, 36-42. [CrossRef]

18. Shin, P.-K. The $\mathrm{pH}$-sensing and light-induced drift properties of titanium dioxide thin films deposited by MOCVD. Appl. Surf. Sci. 2003, 214, 214-221. [CrossRef]

19. Lai, C.-S.; Yang, C.-M.; Lu, T.-F. Thickness Effects on pH Response of HfO2 Sensing Dielectric Improved by Rapid Thermal Annealing. Jpn. J. Appl. Phys. 2006, 45, 3807. [CrossRef]

20. Lai, C.-S.; Yang, C.-M.; Lu, T.-F. pH Sensitivity Improvement on $8 \mathrm{~nm}$ Thick Hafnium Oxide by Post Deposition Annealing. Electrochem. Solid-State Lett. 2006, 9, G90-G92. [CrossRef]

21. Lai, C.-S.; Lu, T.-F.; Yang, C.-M.; Lin, Y.-C.; Pijanowska, D.-G.; Jaroszewicz, B. Body effect minimization using single layer structure for pH-ISFET applications. Sens. Actuators B Chem. 2010, 143, 494-499. [CrossRef]

22. Wal, P.D.; Briand, D.; Mondin, G.; Jenny, S.; Jeanneret, S.; Millon, C.; Roussel, H.; Dubourdieu, C.; de Rooij, N.F. High-k dielectrics for use as ISFET gate oxides. IEEE Sens. 2004, 2, 677-680.

23. Rauwel, E.; Rochat, N. Growth by Liquid-Injection MOCVD and Properties of HfO2 Films for Microelectronic Applications. Chem. Vap. Depos. 2006, 12, 187-192.

24. Alnuaimi, A.; Almansouri, I.; Saadat, I.; Nayfeh, A. High performance graphene-silicon Schottky junction solar cells with HfO2 interfacial layer grown by atomic layer deposition. Sol. Energy 2018, 164, 174-179. [CrossRef]

25. Knez, M.; Nielsch, K.; Niinistö, L. Synthesis and Surface Engineering of Complex Nanostructures by Atomic Layer Deposition. Adv. Mater. 2007, 19, 3425-3438. [CrossRef]

26. Rafí, J.M.; Campabadal, F.; Ohyama, H.; Takakura, K.; Tsunoda, I.; Zabala, M.; Beldarrain, O.; González, M.B.; García, H.; Castán, $\mathrm{H}$; ; et al. $2 \mathrm{MeV}$ Electron Irradiation Effects on the Electrical Characteristics of Metal-Oxide-Silicon Capacitors with Atomic Layer Deposited Al2O3, HfO2 and Nanolaminated Dielectrics. Solid-State Electron. 2013, 79, 65-74. [CrossRef]

27. Hausmann, D.-M.; Gordon, R.-G. Surface morphology and crystallinity control in the atomic layer deposition (ALD) of hafnium and zirconium oxide thin films. J. Cryst. Growth 2003, 249, 251-261. [CrossRef]

28. Campabadal, F.; Rafí, J.M.; Zabala, M.; Beldarrain, O.; Faigón, A.; Castán, H.; Gómez, A.; García, H.; Dueñas, S. Electrical Characteristics of Metal-Insulator-Semiconductor Structures with Atomic Layer Deposited Al2O3, HfO2, and Nanolaminates on Different Silicon Substrates. J. Vac. Sci. Technol. B 2011, 29, 01AA07. [CrossRef]

29. Martín, G.; González, M.B.; Campabadal, F.; Peiró, F.; Cornet, A.; Estradé, S. Transmission electron microscopy assessment of conductive-filament formation in Ni-HfO2-Si resistive-switching operational devices. Appl. Phys. Express 2017, $11,14101$. [CrossRef]

30. García, H.; Castán, H.; Dueñas, S.; Bailón, L.; Campabadal, F.; Beldarrain, O.; Zabala, M.; González, M.B.; Rafí, J.M. Electrical characterization of atomic-layer-deposited hafnium oxide films from hafnium tetrakis(dimethylamide) and water/ozone: Effects of growth temperature, oxygen source, and postdeposition annealing. J. Vac. Sci. Technol. Vac. Surf. Films 2012, 31, $01 \mathrm{~A} 127$. [CrossRef]

31. Braik, M.; Dridi, C.; Ben Ali, M.; Ali, M.; Abbas, M.; Zabala, M.; Bausells, J.; Zine, N.; Jaffrezic-Renault, N.; Errachid, A. Development of a capacitive chemical sensor based on $\mathrm{Co}(\mathrm{II})$-phthalocyanine acrylate-polymer $/ \mathrm{HfO}_{2} / \mathrm{SiO} 2 / \mathrm{Si}$ for detection of perchlorate. J. Sens. Sens. Syst. 2015, 4, 17-23. [CrossRef]

32. Barhoumi, L.; Baraket, A.; Nooredeen, N.M.; Ali, M.B.; Abbas, M.N.; Bausells, J.; Errachid, A. Silicon Nitride Capacitive Chemical Sensor for Phosphate Ion Detection Based on Copper Phthalocyanine-Acrylate-polymer. Electroanalysis 2017, 29, 1586-1595. [CrossRef]

33. Zafar, S.; D’Emic, C.; Afzali, A.; Fletcher, B.; Zhu, Y.; Ning, T. Optimization of PH Sensing Using Silicon Nanowire Field Effect Transistors with HfO2as the Sensing Surface. Nanotechnology 2011, 22, 405501. [CrossRef] [PubMed]

34. Wang, I.-S.; Lin, Y.-T.; Huang, C.-H.; Lu, T.-F.; Lue, C.-E.; Yang, P.; Pijanswska, D.G.; Yang, C.-M.; Wang, J.-C.; Yu, J.-S.; et al. Immobilization of enzyme and antibody on ALD-HfO2-EIS structure by NH3 plasma treatment. Nanoscale Res. Lett. 2012, 7, 179. [CrossRef] [PubMed]

35. Lee, M.; Baraket, A.; Zine, N.; Zabala, M.; Campabadal, F.; Renault, N.-J.; Errachid, A. Impedance Characterization of the Capacitive Field-Effect PH-Sensor Based on a Thin-Layer Hafnium Oxide Formed by Atomic Layer Deposition. Sens. Trans. 2014, 27, 233-238.

36. Ameur, S.; Maupas, H.; Martelet, C.; Jaffrezic-Renault, N.; Ben Ouada, H.; Cosnier, S.; Labbe, P. Impedimetric measurements on polarized functionalized platinum electrodes: Application to direct immunosensing. Mater. Sci. Eng. C 1997, 5, 111-119. [CrossRef]

37. Barhoumi, H.; Haddad, R.; Maaref, A.; Bausells, J.; Bessueille, F.; Léonard, D.; Jaffrezic-Renault, N.; Martelet, C.; Zine, N.; Errachid, A. Na+-implanted membrane for a capacitive sodium electrolyte-Insulator-Semiconductor microsensors. Sens. Lett. 2008, 6, 204-208. [CrossRef] 